\title{
Minerály skupiny columbitu a mikrolitu v granitovom pegmatite pri Liešt'anoch: prvý výskyt vzácnoprvkovej Nb-Ta mineralizácie v Strážovských vrchoch (Slovenská republika)
}

\author{
Minerals of columbite and microlite groups in granitic pegmatite near Liešt'any: the \\ first occurrence of rare-element Nb-Ta mineralization in the Strážovské vrchy Mts. \\ (Slovak Republic)
}

\author{
Pavel Uher ${ }^{1)^{*}}$, Martin Števko ${ }^{2,3)}$ a Sergil Kurylo4) \\ 1)Katedra mineralógie a petrológie, Prírodovedecká fakulta, Univerzita Komenského, Ilkovičova 6, 84215 Bratislava, \\ Slovenská republika; *e-mail: pavel.uher@uniba.sk \\ 2)Ústav vied o Zemi, Slovenská akadémia vied, Dúbravská cesta 9, 84005 Bratislava, Slovenská republika \\ 3)Mineralogicko-petrologické oddělení, Národní muzeum, Cirkusová 1740, 19300 Praha 9 - Horní Počernice, \\ Česká republika \\ 4) Ústav vied o Zemi, Slovenská akadémia vied, pracovisko Banská Bystrica, Duumbierska 1, 97401 Banská Bystrica, \\ Slovenská republika
}

UHeR P, ŠTeVko M, KURYLo S (2020) Minerály skupiny columbitu a mikrolitu v granitovom pegmatite pri Liešt’anoch: prvý výskyt vzácnoprvkovej Nb-Ta mineralizácie v Strážovských vrchoch (Slovenská republika). Bull Mineral Petrolog 28(2): 347-352. ISSN 2570-7337

\begin{abstract}
Accessory minerals of columbite and microlite groups were identified in granitic pegmatite dike intruded into parental Carboniferous ( $350 \mathrm{Ma}$ ) leucogranites of the crystalline basement of the Tatric Unit, Central Western Carpathians. The pegmatite is situated on E slope of Bystrý Hill near Lieštany village, the Strážovské vrchy Mts., Slovakia. Primary columbite-(Fe) forms euhedral crystal ( $\sim 3 \mathrm{~mm}$ across) with diffuse internal zoning reflecting a relatively small compositional variations: $\mathrm{Mn} /(\mathrm{Mn}+\mathrm{Fe})=0.40-0.45$ and $\mathrm{Ta} /(\mathrm{Ta}+\mathrm{Nb})=0.21-0.24$. Secondary anhedral domains of Ta-rich columbite-(Fe) to tantalite-(Fe) $(\leq 200 \mu \mathrm{m})$ with $\mathrm{Mn} /(\mathrm{Mn}+\mathrm{Fe})=0.45-0.47 \mathrm{and} \mathrm{Ta} /(\mathrm{Ta}+\mathrm{Nb})=0.45-0.62 \mathrm{partly}$ replace primary columbite-(Fe) along crystal rims. Moreover, secondary subhedral crystals of microlite-group minerals $(\leq 25 \mu \mathrm{m})$ form fracture fillings in columbite-(Fe). The microlites show uniform high $\mathrm{Ta} /(\mathrm{Ta}+\mathrm{Nb})$ ratio $(0.77-0.80)$ and $\mathrm{U}$ content (7.7 - 10.2 wt.\% UO ; $0.18-0.21 \mathrm{U}$ apfu) but different contents of $\mathrm{F}, \mathrm{Ca}, \mathrm{Na}$ and $\mathrm{Pb}$ : central parts locally show fluorcalciomicrolite composition ( 2 wt.\% F, 9.5 wt.\% CaO, 2.2 - 2.7 wt.\% $\mathrm{Na}_{2} \mathrm{O}$ ), whereas main microlite mass forms zero-valent-dominant microlite with inclusions $(\leq 8 \mu \mathrm{m})$ of Pb-rich zero-valent-dominant microlite (16.8 - $19.7 \mathrm{wt} \% \mathrm{PbO}$; $0.46-0.56 \mathrm{~Pb}$ apfu). Textural relationships and chemical compositions of $\mathrm{Nb}$-Ta minerals indicate primary magmatic origin of columbite-(Fe) and post-magmatic (early subsolidus to late hydrothermal) formation of secondary Ta-rich columbite-(Fe) to tantalite-(Fe) and microlite-group minerals.
\end{abstract}

Key words: columbite-(Fe), $\mathrm{Pb}-\mathrm{U}$ rich microlite, $\mathrm{Nb}$-Ta oxide minerals, granitic pegmatite, Lieštany, Strážovské vrchy Mts., Western Carpathians, Slovak Republic

Obdrženo 6. 10. 2020; prijjato 18. 11. 2020

\section{Úvod}

Oxidické minerály $\mathrm{Nb}$ a Ta patria medzi charakteristické akcesorické fázy vysoko frakcionovaných granitových pegmatitov, ktoré sú klasifikované v rámci muskovitovovzácnoprvkovej, vzácnoprvkovej a miarolitickej triedy (Černý, Ercit 2005). Vnútorná zonalita a textúra, ako aj variácie chemického zloženia minerálov $\mathrm{Nb}$-Ta (hlavne skupina columbitu, tapiolitu, wodginitu, superskupina pyrochlóru, REE-Ti-Nb-Ta oxidy), najmä pomer $\mathrm{Ta} /(\mathrm{Ta}+\mathrm{Nb})$ a $\mathrm{Mn} /(\mathrm{Mn}+\mathrm{Mg})$, ako aj obsahy $\mathrm{Mg}, \mathrm{Ca}, \mathrm{REE}, \mathrm{Ti}, \mathrm{Sn}, \mathrm{W}$, $\mathrm{U}, \mathrm{Na}, \mathrm{Li}, \mathrm{F}$ atd'. sú významnými genetickými indikátormi stupňa geochemickej frakcionácie a magmatickej až hydrotermálnej evolúcie, prípadne neskoršej metamorfnej transformácie granitových pegmatitov (napr. Černý et al. 1986, 1992; Novák et al. 2003; Škoda, Novák 2007; van Lichtervelde et al. 2007; Rao et al. 2009; Chudík et al. 2011; Melcher et al. 2015; Galliski et al. 2016).

Na území Slovenska, respektíve Západných Karpát, boli granitové pegmatity so vzácnoprvkovou Be-Nb-Ta mineralizáciou identifikované pomerne nedávno, od 80 . rokov 20. storočia. $V$ týchto vyššie frakcionovaných pegmatitoch vystupujú akcesorické oxidické minerály $\mathrm{Nb}$-Ta, najmä zo skupiny columbitu, superskupiny pyrochlóru a $\mathrm{Nb}$-Ta rutil, ojedinele členy skupiny wodginitu, ferotapiolit, fersmit, stibiotantalit, Nb-Ta armalcolit až pseudobrookit (napr. Uher 2000, 2008, 2019; Uher et al. 1994, 1998a, b, 2007; Uher, Broska 1995; Novák et al. 2000; 


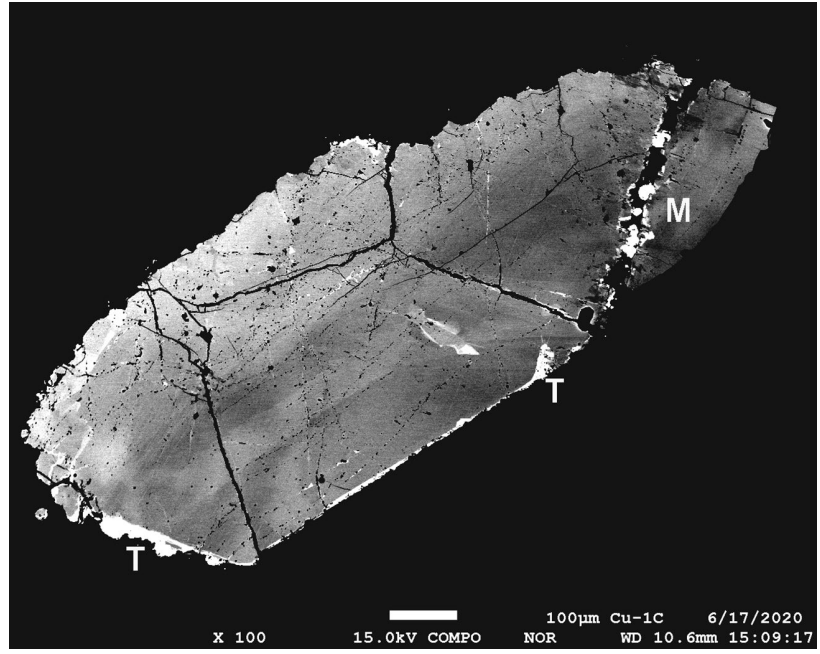

Obr. 1 Nevýrazne difúzne zonálny kryštál columbitu-(Fe), po okrajoch zatláčaný Ta-obohateným columbitom- $(F e)$ až tantalitom-(Fe) (T) a minerálmi skupiny mikrolitu po trhline (M). Pegmatit pri Liešt’anoch. BSE foto S. Kurylo.

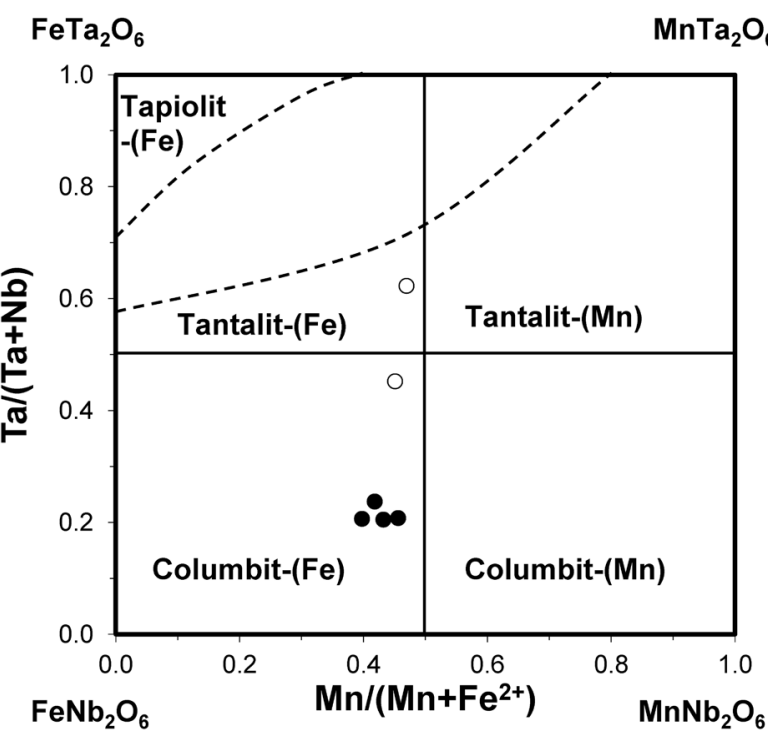

Obr. 2 Štvorcový diagram chemického zloženia columbitu(Fe) (•) a Ta-obohateného columbitu-(Fe) až tantalitu(Fe)(o) z pegmatitu pri Liešt’anoch (atómové množstvá).
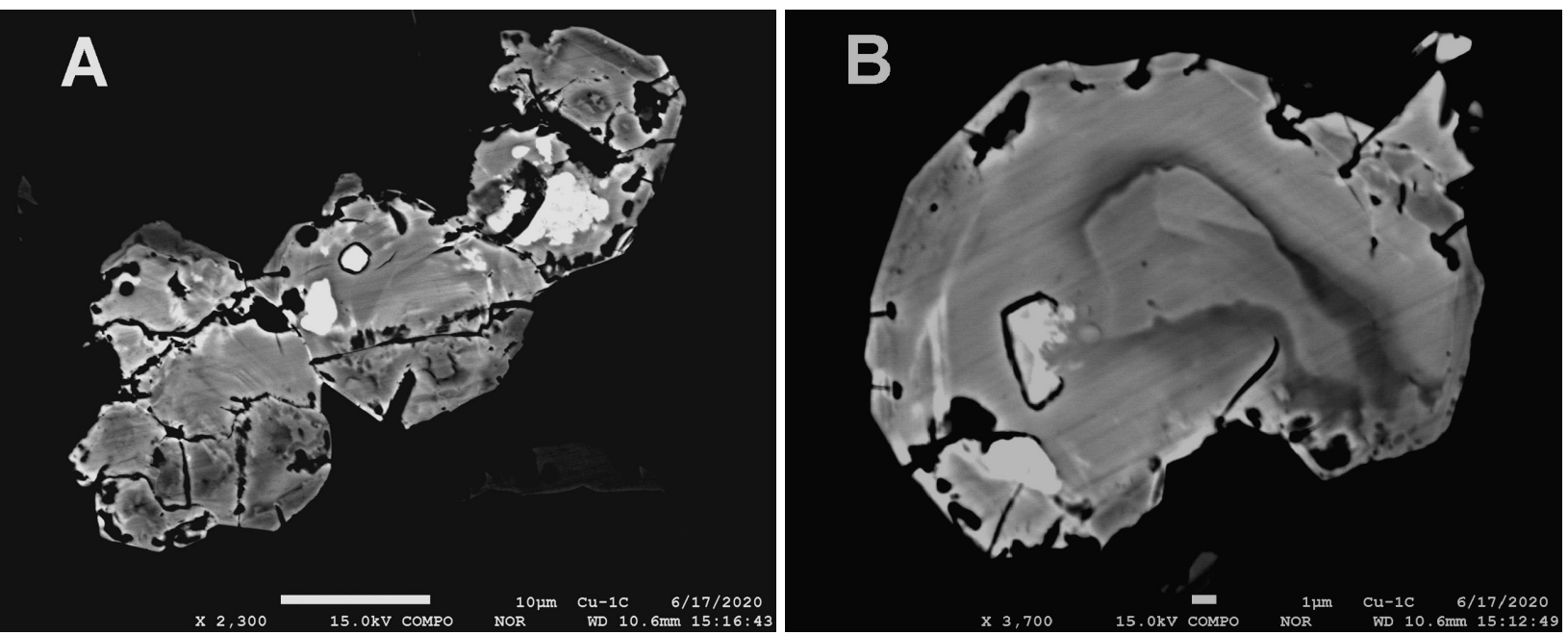

Obr. 3A-B Minerály skupiny mikrolitu z pegmatitu pri Liešt’anoch: fluórkalciomikrolit (centrálna čast' kryštálu - A), mikrolit s deficitom A-katiónov (centrálne až okrajové časti kryštálov - A-B) a Pb-obohatený mikrolit s deficitom A-katiónov (biele inklúzie - A-B). BSE foto S. Kurylo.
Chudík, Uher 2009; Chudík et al. 2011). Uvedené granitové pegmatity s prítomnost'ou minerálov $\mathrm{Nb}$-Ta sa vyskytujú v podobe zonálnych žíl (výplní puklín) až šošovkovitých telies $v$ materských variských (karbónskych) granitických horninách alebo $v$ bezprostredne susediacich paleozoických metamorfovaných horninách (najmä pararulách) v rámci kryštalinika tektonickej jednotky tatrika. Doteraz boli zaznamenané v Malých Karpatoch, Považskom Inovci, Žiari a Nízkych Tatrách (Uher 2019).

Náš príspevok charakterizuje nový nález Nb-Ta minerálov $v$ granitovom pegmatite pri Liešt'anoch, ktorý predmineralizácie $v$ regióne Strážovských vrchov a súčasne dopíňa náš obraz o regionálnom rozšírení tejto mineralizácie $v$ rámci variských pegmatitov tatrika Západných Karpát. Okrem dominantného columbitu-(Fe) sme identifikovali aj mladšiu asociáciu s tantalitom-(Fe) a minerálmi skupiny mikrolitu, vrátane vzácnych členov obohatených olovom.

\section{Lokalizácia a geologická charakeristika pegmatitu}

Študovaný granitový pegmatit sa nachádza v južnej časti Strážovských vrchov, na východnom svahu kóty Bystrý vrch (792.3 m n. m.), približne $3.5 \mathrm{~km} \mathrm{sz.} \mathrm{od} \mathrm{obce}$ Liešt'any, respektíve jej miestnej časti Lomnica a približne $15 \mathrm{~km}$ sz. od okresného mesta Prievidza (Trenčiansky kraj) na západnom Slovensku. GPS koordináty výskytu študovaného pegmatitu sú $48.854565^{\circ} \mathrm{N}$ a $18.449947^{\circ}$ E, nadmorská výška je $632 \mathrm{~m}$.

Okolie výskytu pegmatitu patrí do kryštalinického manymi, biotiticko-muskovitickými granitmi $\mathrm{s}$ granátom (almandínom) a sillimanitom, ktoré majú geochemickú afinitu ku granitom S-typu (Hovorka, Fejdi 1983; Mahel' 1985; Vilinovičová 1990; Petrík, Kohút 1997). Granity často plynule prechádzajú do apliticko-pegmatických leukogranitov, v širšom okolí výskytu boli zaznamenané aj paleozoické metamorfované horniny, najmä biotitické pararuly, ktoré sú lokálne migmatitizované, s prechodmi do anatektických granitických hornín (Kahan in Mahel' et al. 1981; Mahel' 1985). Relatívne časté sú výskyty žíl až šošoviek granitových pegmatitov, ktoré intrudujú do pararúl až migmatitov aj granitov (Dávidová 1978; Mahel' 1985). Granitické horniny Strážovských vrchov intrudovali počas stavuje prvý zistený výskyt tohto typu vzácnoprvkovej sívu Suchého, je budované leukokrátnymi peraluminóz- 
variského orogénu; datovanie zirkónu na základe izotopov olova $\left({ }^{207} \mathrm{~Pb} /{ }^{206} \mathrm{~Pb}\right)$ poskytlo spodnokarbónsky vek 356 土 9 Ma (lokalita Chvojnica - Kamenistá dolina; Král' et al. 1997).

Fragmenty granitových pegmatitov vel'kosti do 20 $\times 10 \mathrm{~cm}$ sa na študovanej lokalite sporadicky vyskytujú v sutinách na ploche cca $250 \times 200 \mathrm{~m}$. Na základe štúdia viacerých úlomkov je možné konštatovat', že sa pravdepodobne jedná o niekol'ko samostatných pegmatitových žíl s mocnost'ou do $20 \mathrm{~cm}$ a pomerne nevýraznou zonálnost'ou. Prevláda hrubozrnná kremeňovo-mikroklínovo-muskovitová zóna s lokálnym výskytom blokového mikroklínu a len s minoritným zastúpením masívneho kremeňa $\mathrm{v}$ centrálnej časti žíl (kremenné jadro). Ojedinele boli nájdené aj fragmenty jemnozrnného cukrovitého albitu s granátom. Makroskopické $\mathrm{Nb}$-Ta minerály boli pozorované len $v$ jednom prípade vo fragmente hrubozrnného pegmatitu $\mathrm{s}$ rozmermi 12 $\times 8 \mathrm{~cm}$.

\section{Metodika}

Leštený nábrus s $\mathrm{Nb}$-Ta minerálmi bol študovaný pomocou elektrónového mikroanalyzátora JEOL JXA-8530FE (Ústav vied o Zemi SAV, pracovisko Banská Bystrica) vo vinovo-disperznom móde (WDS). Analytické podmienky merania $\mathrm{Nb}$-Ta minerálov boli nasledovné: urýchl'ovacie napätie $15 \mathrm{kV}$, vzorkový prúd $20 \mathrm{nA}$, čas načítania na píku $20 \mathrm{~s}$ (30 s pre Th, $U$ a Pb) a $10 \mathrm{~s}$ na pozadí. Priemer elektrónového lúča dosahoval 1 až $3 \mu \mathrm{m}$. Použité štandardy, rtg. línie a spodné detekčné limity $(3 \sigma$, $\checkmark \mathrm{ppm}$ ) boli nasledovné: scheelit ( $\mathrm{W} L \alpha$, 640), $\mathrm{LiNbO}_{3}$ (Nb La, 380), $\mathrm{CrTa}_{2} \mathrm{O}_{6}$ ( $\mathrm{Ta}$ $\mathrm{Ma}, 500$ ), rutil (Ti Ka, 490), $\mathrm{ZrO}_{2}$ ( $\mathrm{Zr} \mathrm{La}$, 230), kasiterit (Sn La, 160), $\mathrm{ThO}_{2}$ (Th $\mathrm{Ma}, 180), \mathrm{UO}_{2}(\mathrm{U} \mathrm{M} \beta, 270), \mathrm{ScVO}_{4}$ (Sc $\mathrm{Ka}, 150), \mathrm{YPO}_{4}(\mathrm{Y} \mathrm{La}, 270), \mathrm{CePO}_{4}(\mathrm{Ce}$ La, 920), antimonit (Sb La, 190), BiTe (Bi La, 650), hematit (Fe Ka, 350), rodonit (Mn Ka, 370), willemit (Zn Ka, 770), diopsid (Mg Ka, 100; Ca Ka, 80), krokoit ( $\mathrm{Pb} \mathrm{M \beta}, 340)$, albit (Na Ka, 120) a fluorit (F Ka, 300). Na výpočet koncentrácii prvkov bola použitá korekčná metóda ZAF (Bence, Albee 1968). Na uvedenom prístroji boli urobené snímky minerálov v spätne rozptýlených elektrónoch (BSE).

\section{Výsledky}

Študovaná vzorka je tvorená prizmatickým tabul'kovitým kryštálom columbitu -tantalitu čiernej farby s kovovým leskom o vel'kosti cca $3 \mathrm{~mm}$, ktorý je zarastený $\checkmark$ hrubozrnnom agregáte K-živca, kremeňa a muskovitu. Columbit-tantalit vykazuje v BSE nevýraznú, nepravidelne difúznu vnútornú zonalitu (obr. 1) s relatívne malými variáciami obsahov hlavných a stopových prvkov (tab. 1, anal. 1
- 4); jedná sa o columbit-(Fe) s atómovým pomerom Mn/ $(\mathrm{Mn}+\mathrm{Fe})=0.40-0.46, \mathrm{Ta} /(\mathrm{Ta}+\mathrm{Nb})=0.21-0.24$ (obr. 2), $0.2-0.3 \mathrm{hm} . \% \mathrm{TiO}_{2}(0.010-0.015 \mathrm{Ti}$ apfu), obsahy ostatných meraných prvkov sú vel'mi nízke (pod 0.005 apfu). Uvedená hlavná masa tohto primárneho columbitu-(Fe) je po okraji kryštálu zatláčaná nepravidelnými doménami ( 20 - $100 \mu \mathrm{m})$, svetlejšími v BSE (obr. 1), ktoré na základe chemického zloženia možno klasifikovat' ako Ta-obohatený columbit-(Fe) až tantalit-(Fe) s $\mathrm{Mn} /(\mathrm{Mn}+\mathrm{Fe})$ $=0.45-0.47 \mathrm{a} \mathrm{Ta} /(\mathrm{Ta}+\mathrm{Nb})=0.45-0.62$ (obr. 2), pričom obsahy Ti a ostatných meraných prvkov sú podobné ako v prípade primárneho columbitu-(Fe) (tab. 1, anal. 5 - 6).

Tabul'ka 1 Chemické zloženie primárneho columbitu-(Fe) (anal. 1 - 4) a sekundárneho columbitu-(Fe) až tantalitu-(Fe) (anal. 5 - 6) z pegmatitu Lieštany, Bystrý vrch (hm. \%).

\begin{tabular}{|c|c|c|c|c|c|c|}
\hline Minerál & Col-(Fe) & Col-(Fe) & Col-(Fe) & Col-(Fe) & Col-(Fe) & Tan-(Fe) \\
\hline Anal. & 1 & 2 & 3 & 4 & 5 & 6 \\
\hline $\mathrm{WO}_{3}$ & 0.22 & 0.18 & 0.10 & 0.24 & 0.00 & 0.38 \\
\hline $\mathrm{Nb}_{2} \mathrm{O}_{5}$ & 55.35 & 55.45 & 52.66 & 54.93 & 34.10 & 21.77 \\
\hline $\mathrm{Ta}_{2} \mathrm{O}_{5}$ & 23.71 & 23.97 & 27.20 & 23.98 & 46.84 & 59.84 \\
\hline $\mathrm{TiO}_{2}$ & 0.31 & 0.26 & 0.29 & 0.21 & 0.32 & 0.21 \\
\hline $\mathrm{ZrO}_{2}$ & 0.10 & 0.03 & 0.06 & 0.09 & 0.04 & 0.00 \\
\hline $\mathrm{SnO}_{2}$ & 0.07 & 0.11 & 0.10 & 0.12 & 0.00 & 0.04 \\
\hline $\mathrm{UO}_{2}$ & 0.04 & 0.00 & 0.00 & 0.00 & 0.00 & 0.07 \\
\hline $\mathrm{Sc}_{2} \mathrm{O}_{3}$ & 0.00 & 0.00 & 0.04 & 0.00 & 0.04 & 0.05 \\
\hline $\mathrm{Ce}_{2} \mathrm{O}_{3}$ & 0.00 & 0.10 & 0.00 & 0.12 & 0.00 & 0.29 \\
\hline $\mathrm{Bi}_{2} \mathrm{O}_{3}$ & 0.19 & 0.00 & 0.14 & 0.00 & 0.25 & 0.00 \\
\hline $\mathrm{Fe}_{2} \mathrm{O}_{3}$ & 1.54 & 0.83 & 0.98 & 2.53 & 2.45 & 2.40 \\
\hline $\mathrm{FeO}$ & 10.30 & 11.10 & 10.59 & 9.56 & 8.54 & 7.72 \\
\hline $\mathrm{MnO}$ & 7.74 & 7.24 & 7.51 & 7.91 & 6.92 & 6.75 \\
\hline $\mathrm{ZnO}$ & 0.03 & 0.13 & 0.00 & 0.09 & 0.00 & 0.00 \\
\hline $\mathrm{MgO}$ & 0.00 & 0.00 & 0.00 & 0.00 & 0.07 & 0.00 \\
\hline Suma & 99.59 & 99.39 & 99.67 & 99.77 & 99.57 & 99.51 \\
\hline W & 0.004 & 0.003 & 0.002 & 0.004 & 0.000 & 0.007 \\
\hline $\mathrm{Nb}$ & 1.556 & 1.565 & 1.502 & 1.540 & 1.064 & 0.729 \\
\hline Ta & 0.401 & 0.407 & 0.467 & 0.404 & 0.879 & 1.204 \\
\hline $\mathrm{Ti}$ & 0.015 & 0.012 & 0.014 & 0.010 & 0.017 & 0.012 \\
\hline $\mathrm{Zr}$ & 0.003 & 0.001 & 0.002 & 0.003 & 0.001 & 0.000 \\
\hline Sn & 0.002 & 0.003 & 0.002 & 0.003 & 0.000 & 0.001 \\
\hline $\mathrm{Fe}^{3+} \mathrm{B}$ & 0.019 & 0.009 & 0.011 & 0.036 & 0.039 & 0.047 \\
\hline Suma $B$ & 2.000 & 2.000 & 2.000 & 2.000 & 2.000 & 2.000 \\
\hline$U$ & 0.001 & 0.000 & 0.000 & 0.000 & 0.000 & 0.001 \\
\hline Sc & 0.000 & 0.000 & 0.002 & 0.000 & 0.002 & 0.003 \\
\hline $\mathrm{Ce}$ & 0.000 & 0.002 & 0.000 & 0.003 & 0.000 & 0.008 \\
\hline $\mathrm{Bi}$ & 0.003 & 0.000 & 0.002 & 0.000 & 0.004 & 0.000 \\
\hline $\mathrm{Fe}^{3+}$ & 0.053 & 0.030 & 0.036 & 0.082 & 0.088 & 0.086 \\
\hline $\mathrm{Fe}^{2+}$ & 0.536 & 0.580 & 0.559 & 0.496 & 0.493 & 0.478 \\
\hline $\mathrm{Mn}$ & 0.408 & 0.383 & 0.402 & 0.416 & 0.405 & 0.423 \\
\hline $\mathrm{Zn}$ & 0.001 & 0.006 & 0.000 & 0.004 & 0.000 & 0.000 \\
\hline $\mathrm{Mg}$ & 0.000 & 0.000 & 0.000 & 0.000 & 0.007 & 0.000 \\
\hline Suma $A$ & 1.002 & 1.001 & 1.001 & 1.001 & 0.999 & 0.999 \\
\hline $\mathrm{O}$ & 6.000 & 6.000 & 6.000 & 6.000 & 6.000 & 6.000 \\
\hline $\mathrm{Mn} /\left(\mathrm{Mn}+\mathrm{Fe}^{2+)}\right.$ & 0.432 & 0.398 & 0.418 & 0.456 & 0.451 & 0.469 \\
\hline $\mathrm{Ta} /(\mathrm{Ta}+\mathrm{Nb})$ & 0.205 & 0.206 & 0.237 & 0.208 & 0.452 & 0.623 \\
\hline
\end{tabular}

Empirické vzorce boli vypočítané na základe $O=6$ atómov, $A+B=3$ atómy a valenčného prepočtu $\mathrm{Fe}^{3+}$ a $\mathrm{Fe}^{2+}$. Obsahy Th, $\mathrm{Sb}, \mathrm{Y}, \mathrm{Ca}, \mathrm{Pb}$ a Na boli pod spodným detekčným limitom elektrónového mikroanalyzátora. 
Tabul'ka 2 Chemické zloženie fluórkalciomikrolitu (anal. 1 - 2) a mikrolitu s deficitom A-katiónov (anal. 3 - 7; Pb-obohatený anal. 6 - 7) z pegmatitu Liešt'any, Bystrý vrch (hm. \%).

\begin{tabular}{|c|c|c|c|c|c|c|c|}
\hline \multirow{2}{*}{$\begin{array}{l}\text { Minerál } \\
\text { Anal. }\end{array}$} & \multicolumn{2}{|c|}{ Fluórkalciomikrolit } & \multicolumn{5}{|c|}{ Mikrolit s deficitom A-katiónov } \\
\hline & 1 & 2 & 3 & 4 & 5 & 6 & 7 \\
\hline $\mathrm{WO}_{3}$ & 0.55 & 0.59 & 0.14 & 0.29 & 0.26 & 0.33 & 0.38 \\
\hline $\mathrm{Nb}_{2} \mathrm{O}_{5}$ & 9.71 & 10.12 & 9.45 & 9.59 & 9.95 & 9.28 & 9.05 \\
\hline $\mathrm{Ta}_{2} \mathrm{O}_{5}$ & 62.68 & 61.70 & 59.12 & 62.76 & 62.58 & 54.46 & 51.70 \\
\hline $\mathrm{TiO}_{2}$ & 0.93 & 1.08 & 1.13 & 0.95 & 0.92 & 1.02 & 0.76 \\
\hline $\mathrm{ZrO}_{2}$ & 0.00 & 0.03 & 0.00 & 0.06 & 0.00 & 0.00 & 0.00 \\
\hline $\mathrm{UO}_{2}$ & 10.24 & 10.25 & 10.22 & 9.96 & 9.37 & 8.46 & 7.66 \\
\hline $\mathrm{Sc}_{2} \mathrm{O}_{3}$ & 0.06 & 0.04 & 0.05 & 0.00 & 0.08 & 0.00 & 0.00 \\
\hline $\mathrm{Ce}_{2} \mathrm{O}_{3}$ & 0.16 & 0.34 & 0.00 & 0.34 & 0.38 & 0.34 & 0.36 \\
\hline $\mathrm{Sb}_{2} \mathrm{O}_{3}$ & 0.24 & 0.15 & 0.18 & 0.26 & 0.23 & 0.24 & 0.11 \\
\hline $\mathrm{Bi}_{2} \mathrm{O}_{3}$ & 0.00 & 0.00 & 0.10 & 0.21 & 0.00 & 0.00 & 0.09 \\
\hline $\mathrm{FeO}$ & 0.42 & 0.38 & 0.68 & 0.81 & 0.61 & 1.08 & 1.69 \\
\hline $\mathrm{MnO}$ & 0.20 & 0.19 & 0.44 & 0.34 & 0.30 & 0.56 & 0.29 \\
\hline $\mathrm{CaO}$ & 9.45 & 9.55 & 1.93 & 1.42 & 2.82 & 0.43 & 0.64 \\
\hline $\mathrm{SnO}$ & 0.85 & 0.90 & 0.65 & 0.78 & 0.81 & 0.70 & 0.84 \\
\hline $\mathrm{PbO}$ & 0.13 & 0.11 & 2.37 & 2.92 & 3.56 & 16.77 & 19.71 \\
\hline $\mathrm{Na} 2 \mathrm{O}$ & 2.25 & 2.70 & 0.00 & 0.00 & 0.04 & 0.19 & 0.11 \\
\hline$F$ & 1.92 & 2.00 & 0.24 & 0.32 & 0.28 & 0.24 & 0.18 \\
\hline $\mathrm{O}=\mathrm{F}$ & -0.81 & -0.84 & -0.10 & -0.13 & -0.12 & -0.10 & -0.08 \\
\hline Suma & 98.98 & 99.28 & 86.58 & 90.88 & 92.07 & 93.99 & 93.50 \\
\hline W & 0.013 & 0.014 & 0.003 & 0.007 & 0.006 & 0.009 & 0.010 \\
\hline $\mathrm{Nb}$ & 0.394 & 0.410 & 0.402 & 0.390 & 0.404 & 0.423 & 0.435 \\
\hline $\mathrm{Ta}$ & 1.530 & 1.503 & 1.514 & 1.536 & 1.528 & 1.492 & 1.494 \\
\hline $\mathrm{Ti}$ & 0.063 & 0.073 & 0.080 & 0.064 & 0.062 & 0.077 & 0.061 \\
\hline $\mathrm{Zr}$ & 0.000 & 0.001 & 0.000 & 0.003 & 0.000 & 0.000 & 0.000 \\
\hline Suma $B$ & 2.000 & 2.001 & 1.999 & 2.000 & 2.000 & 2.001 & 2.000 \\
\hline$U$ & 0.205 & 0.204 & 0.214 & 0.199 & 0.187 & 0.190 & 0.181 \\
\hline Sc & 0.005 & 0.003 & 0.004 & 0.000 & 0.006 & 0.000 & 0.000 \\
\hline $\mathrm{Ce}$ & 0.005 & 0.011 & 0.000 & 0.011 & 0.012 & 0.013 & 0.014 \\
\hline $\mathrm{Sb}$ & 0.009 & 0.006 & 0.007 & 0.010 & 0.009 & 0.010 & 0.005 \\
\hline $\mathrm{Bi}$ & 0.000 & 0.000 & 0.002 & 0.005 & 0.000 & 0.000 & 0.002 \\
\hline $\mathrm{Fe}$ & 0.032 & 0.028 & 0.054 & 0.061 & 0.046 & 0.091 & 0.150 \\
\hline $\mathrm{Mn}$ & 0.015 & 0.014 & 0.035 & 0.026 & 0.023 & 0.048 & 0.026 \\
\hline $\mathrm{Ca}$ & 0.909 & 0.916 & 0.195 & 0.137 & 0.271 & 0.046 & 0.073 \\
\hline Sn & 0.034 & 0.036 & 0.027 & 0.031 & 0.032 & 0.031 & 0.040 \\
\hline $\mathrm{Pb}$ & 0.003 & 0.003 & 0.060 & 0.071 & 0.086 & 0.455 & 0.564 \\
\hline $\mathrm{Na}$ & 0.392 & 0.469 & 0.000 & 0.000 & 0.007 & 0.037 & 0.023 \\
\hline Suma $A$ & 1.609 & 1.690 & 0.598 & 0.551 & 0.679 & 0.921 & 1.078 \\
\hline Vakancia $A$ & 0.391 & 0.310 & 1.402 & 1.449 & 1.321 & 1.079 & 0.922 \\
\hline$F$ & 0.545 & 0.566 & 0.071 & 0.091 & 0.080 & 0.076 & 0.060 \\
\hline $\mathrm{O}$ & 6.329 & 6.357 & 5.745 & 5.688 & 5.809 & 6.030 & 6.203 \\
\hline Suma an. & 6.874 & 6.923 & 5.816 & 5.779 & 5.889 & 6.106 & 6.263 \\
\hline $\mathrm{Ta} /(\mathrm{Ta}+\mathrm{Nb})$ & 0.795 & 0.786 & 0.790 & 0.798 & 0.791 & 0.779 & 0.774 \\
\hline $\mathrm{Mn} /(\mathrm{Mn}+\mathrm{Fe})$ & 0.319 & 0.333 & 0.393 & 0.299 & 0.333 & 0.345 & 0.148 \\
\hline
\end{tabular}

Empirické vzorce boli vypočítané na základe sumy $B=2$ atómy. Obsahy Th, Y, V, Zn a Mg boli pod spodným detekčným limitom elektrónového mikroanalyzátora.
Kryštál primárneho columbitu(Fe) je pretínaný cca $35 \mu \mathrm{m}$ hrubou puklinou, čiastočne vyplnenou minerálmi skupiny mikrolitu (obr. 1 a 3). Minerály skupiny mikrolitu tvoria hypidiomorfné až xenomorfné jedince s vel'kost'ou $15-25 \mu \mathrm{m}$, s náznakmi kryštálových plôch (obr. 3). Hlavnú hmotu minerálov skupiny mikrolitu tvorí fluórkalciomikrolit (centrálne zóny) až mikrolit s deficitom A-katiónov (centrálne až okrajové zóny) s jemnou koncentrickou až oscilačnou rastovou zonalitou, s nepravidelnými cca 1 - 8 $\mu \mathrm{m}$ inklúziami fázy, ktorú možno klasifikovat' ako Pb-obohatený mikrolit s deficitom A-katiónov (obr. 3A-B). Kým fluórkalciomikrolit sa vyznačuje vysokými obsahmi Ca ( 0.9 apfu), Na ( 0.4 apfu), F ( 0.6 apfu) a nízkymi obsahmi $\mathrm{Pb}(\sim 0.003 \mathrm{apfu})$ a nižším deficitom katiónov v pozícií A (0.3 - $0.4 a p f u)$, oba typy mikrolitov $s$ deficitom $A$-katiónov majú podstatne nižšie obsahy $\mathrm{Ca}(0.05-0.3$ apfu), $\mathrm{Na}(\leq 0.04 \mathrm{apfu})$ a F (0.2 - 0.3 apfu), avšak vykazujú zvýšené obsahy $\mathrm{Pb}(\leq 0.56$ apfu, $\leq 19.7 \mathrm{hm}$. \% $\mathrm{PbO}$ v Pb-obohatenej fáze); obsahy U dosahujú 0.18 - 0.21 apfu ( 8 - 10 hm. \% UO ${ }_{2}$ ) vo všetkých troch mikrolitových fázach (tab. 2). Ukazuje sa tak výrazná negatívna korelácia, respektíve antagonizmus medzi obsahmi $\mathrm{Ca}$ a $\mathrm{Pb}$ (obr. 4), respektíve medzi $\mathrm{Ca}, \mathrm{Na}$ a $\mathrm{F}$ na jednej strane a $\mathrm{Pb}$ a deficitom katiónov $\mathrm{v}$ pozícií $A$ na strane druhej, čo naznačuje možnú substitúciu typu ${ }^{A}$ (vakancia, $\left.\mathrm{H}_{2} \mathrm{O}\right)+{ }^{A} \mathrm{~Pb}^{2+}+{ }^{Y}\left(\right.$ vakancia, $\left.\mathrm{H}_{2} \mathrm{O}\right)=$ ${ }^{A} \mathrm{Ca}^{2+}+{ }^{A} \mathrm{Na}+{ }^{Y} \mathrm{~F}^{-}$. Presnejšiu klasifikáciu minerálov skupiny mikrolitu, najmä členov $\mathrm{s}$ dominantným deficitom A-katiónov, však možno aplikovat' len $v$ prípade exaktného stanovenia množstva molekulovej vody a $(\mathrm{OH})^{-}$v pozíciach $A$ a $Y$, prípadne aj $X$.

\section{Diskusia a záver}

Študovaná lokalita pegmatitu pri Liešt'anoch predstavuje prvý známy výskyt $\mathrm{Nb}$-Ta mineralizácie $v$ regióne Strážovských vrchov, čo dopĺn̆a naše poznatky o plošnom rozšírení variských granitových pegmatitov so vzácnoprvkovou mineralizáciou v kryštaliniku Západných Karpát. Ukazuje sa, že vyššie frakcionované granitové pegmatity s akcesorickým berylom a oxidickými minerálmi NbTa (najmä skupina columbitu a mik- 
rolitu) boli doteraz opísané v rámci masívov materských variských orogénnych granitov S- a l-typu ( 360 - 340 Ma) v rôznych regiónoch tektonickej jednotky tatrika: pohoria Malé Karpaty, Považský Inovec, Žiar, Nízke Tatry a Vysoké Tatry (Uher 2019). Columbit-(Fe) z opisovanej lokality pri Lieštanoch interpretujeme ako primárne magmatický minerál, hoci jeho pôvodná vnútorná zonalita bola pravdepodobne zmazaná neskoršími postmagmatickými procesmi, pričom pozorujeme zrejme sekundárnu, nevýrazne difúznu zonalitu.

Chemické zloženie columbitu-(Fe) je podobné ako na lokalite pegmatitu Ráztočno v pohorí Žiar (Uher 2008), respektíve niektorých pegmatitoch $v$ oblasti Bratislavy (Uher et al. 1994). Jednoznačne mladšie minerály, vel'mi pravdepodobne rano postmagmatického až hydrotermálneho pôvodu, sú sekundárny columbit-(Fe) obohatený Ta až tantalit-(Fe), a najmä minerály skupiny mikrolitu, jasne zatláčajúce primárne magmatický columbit-(Fe). Na základe súčasne platnej klasifikácie a nomenklatúry minerálov superskupiny pyrochlóru (Atencio et al. 2010) možno identifikované fázy, určené len na základe ich neúplného chemického zloženia (elektrónová mikroanalýza), klasifikovat' ako fluórkalciomikrolit, mikrolit s deficitom A-katiónov a Pb-obohatený mikrolit $s$ deficitom A-katiónov. Vel'mi malé rozmery, vzácnost' a chemická heterogenita minerálov skupiny mikrolitu z pegmatitu pri Lieštanoch preto umožnili posledné dve mikrolitové fázy definovat' neurčito len ako mikrolity $\mathrm{s}$ deficitom $A$-katiónov, respektíve s dominanciou nulovo valentnej zložky, teda molekulovej vody a/alebo vakancie v pozícií $A$ (doslova „zero-valent-dominant microlite“ v zmysle nomenklatúry Atencio et al. 2010). Popri zvýšenom obsahu U sú zaujímavé najmä vysoké obsahy $\mathrm{Pb} v$ mikrolite, lokálne dosahujúce takmer $20 \mathrm{hm}$. \% PbO ( $\leq 0.56 \mathrm{~Pb}$ apfu). Takéto silne zvýšené koncentrácie $\mathrm{Pb}$ (lokálne spolu so zvýšenými obsahmi U a Sb) boli zistené aj v mineráloch skupiny mikrolitu z pegmatitu $\vee$ Sopotnickej doline pri Brusne v Nízkych Tatrách (10 - 19 hm. \% PbO, 0.2 - 0.4 Pb apfu), pričom sa predpokladá ich vznik pôsobením externých hydrotermálnych fluíd a genetická spojitost' s ned'alekými žilnými sulfidickými $\mathrm{Pb}$-Sb mineralizáciami (Uher et al. 1998b; Chudík, Uher 2009). V prípade pegmatitu pri Liešt'anoch možno takisto predpokladat' neskorší hydrotermálny vznik minerálov skupiny mikrolitu, avšak ich genetická spojitost' s ned'alekými výskytmi žilnej hydrotermálnej polymetalickej mineralizácie $v$ kryštaliniku Strážovských vrchov s prítomnost'ou galenitu a d'alších sulfidov (Valaská Belá, Čavoj, Gápel, Chvojnica) nie je na základe známych faktov preukázaná, hoci nie je vylúčená. $\mathrm{V}$ každom prípade predstavuje mikrolit $\mathrm{s}$ vysokým obsahom $\mathrm{Pb}$ pomerne vzácny minerál, bližiaci sa svojim zložením ku kenoplumbomikrolitu [ideálne $(\mathrm{Pb} \square)$ $\mathrm{Ta}_{2} \mathrm{O}_{6} \square$ ], raritnému členu skupiny mikrolitu s dominantným zastúpením $\mathrm{Pb} \vee$ pozícií $A$, opísanému z granitového pegmatitu Ploskaja gora na polostrove Kola v Rusku (Atencio et al. 2018).

\section{Pod'akovanie}

Výskum bol finančne podporený projektom VEGA 1/0467/20 a Ministerstvom kultury ČR v rámci inštitucionálneho financovania dlhodobého koncepčného rozvoja výskumnej organizácie Národní muzeum (DKRVO 20192023/1.II.b, 00023272). Autori d'akujú recenzentom M. Novákovi a Š. Ferencovi za konštruktívne pripomienky, ktoré prispeli k vylepšeniu rukopisu.

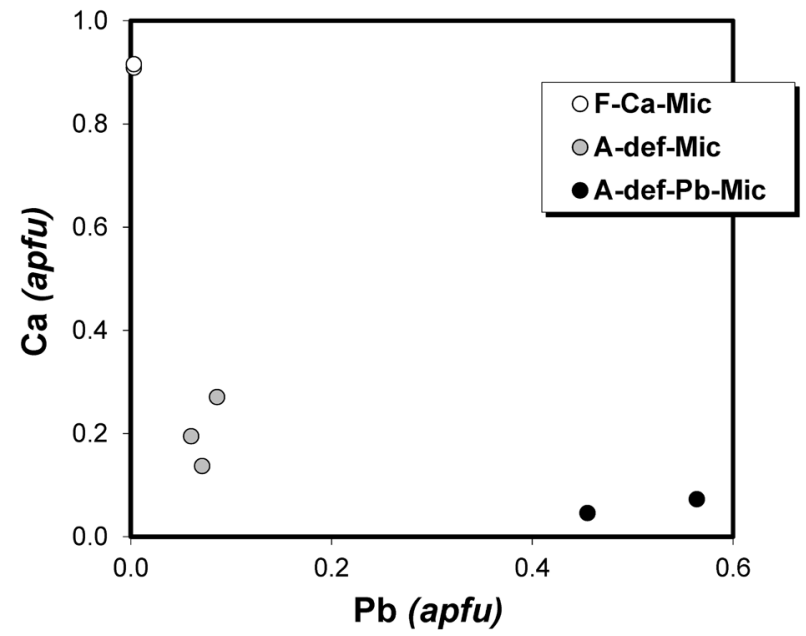

Obr. 4 Ca versus Pb diagram minerálov skupiny mikrolitu z pegmatitu pri Liešt'anoch.

\section{Literatúra}

Atencio D, Andrade MB, Christy AG, Gieré R, Kartashov PM (2010) The pyrochlore supergroup of minerals: nomenclature. Can Mineral 48: 673-698

Atencio D, Andrade MB, Bindi L, Bonazzi P, Zoppi M, StanLEY CJ, KRIStiansen R (2018) Kenoplumbomicrolite, $(\mathrm{Pb}, \square)_{2} \mathrm{Ta}_{2} \mathrm{O}_{6}[\square,(\mathrm{OH}), \mathrm{O}]$, a new mineral from Ploskaya, Kola Peninsula, Russia. Mineral Mag 82: 10491055

Bence AE, Albee AL (1968) Empirical correction factors for the electron microanalysis of silicates and oxides. $J$ Geol 76: 382-403

ČERnÝ P, ERCIT TS (2005) The classification of granitic pegmatites revisited. Can Mineral 43: 2005-2026

Černý P, Goad BE, Hawthorne FC, Chapman R (1986) Fractionation trends of the $\mathrm{Nb}$ - and Ta-bearing oxide minerals in the Greer Lake pegmatite granite and its pegmatite aureole, southeastern Manitoba. Am Mineral 71: 501-517

Černý P, Novák M, Chapman R (1992) Effects of sillimanite-grade metamorphism and shearing on $\mathrm{Nb}$-Ta oxide minerals in granitic pegmatites: Maršíkov, Northern Moravia, Czechoslovakia. Can Mineral 30: 699-718

DÁvIDOVÁ Š (1978) Mineralógia a petrografia pegmatitov kryštalinika tatríd. Miner Slov 10: 127-146

Galliski MÁ, Márquez-Zavalía MF, Černý P, LiRa R (2016) Complex $\mathrm{Nb}$-Ta-Ti-Sn oxide mineral intergrowths in the La Calandria pegmatite, Cañada del Puerto, Córdoba, Argentina. Can Mineral 54: 899-916

Hovorka D, FEJDI P (1983) Garnets of peraluminous granites of the Suchý and the Malá Magura Mts. (the Western Carpathians) - their origin and petrological significance. Geol Zbor Geol Carpath 34: 103-115

CHudík P, UHeR P (2009) Minerály skupiny pyrochlóru z granitových pegmatitov Západných Karpát: variácie chemického zloženia a substitučné mechanizmy. Miner Slov 41: 159-168

Chudík P, Uher P, Gadas P, Škoda R, Pršek J (2011) Niobium-tantalum oxide minerals in the Jezuitské Lesy granitic pegmatite, Bratislava Massif, Slovakia: Ta to $\mathrm{Nb}$ and $\mathrm{Fe}$ to $\mathrm{Mn}$ evolutionary trends in a narrow $\mathrm{Be}$, Cs-rich and Li, B-poor dike. Mineral Petrol 102: 15-27 
KRÁl' J, Hess JC, Kober B, LiPPolt HJ (1997) 207Pb/206Pb and 40Ar/39Ar age data from plutonic rocks of the Strážovské vrchy Mts. basement, Western Carpathians. In Grecula P, Hovorka D, Putiš M (eds.) Geological evolution of the Western Carpathians 253-260. Miner Slov Monograph Bratislava

MAHEL' M (1985) Geologická stavba Strážovských vrchov. 1-221, Geol Ústav D Štúra, Bratislava

MAHEL' M (1981) Geologická mapa Strážovských vrchov. Regionálne geologické mapy Slovenska 1:50 000 . Geol Ústav D Štúra, Bratislava

Melcher F, Graupner T, Gäbler he, Sitnikova M, Henjes-Kunst F, Oberthür T, Gerdes A., Dewaele S (2015) Tantalum-(niobium-tin) mineralisation in African pegmatites and rare metal granites: Constraints from $\mathrm{Ta}-\mathrm{Nb}$ oxide mineralogy, geochemistry and $\mathrm{U}-\mathrm{Pb}$ geochronology. Ore Geol Rev 64: 667-719

Novák M, Uher P, Černý P, Siman P (2000) Compositional variations in ferrotapiolite + tantalite pairs from the beryl-columbite pegmatite at Moravany nad Váhom, Slovakia. Mineral Petrol 69: 295-306

NovÁK M, ČERnÝ P, Uher P (2003) Extreme variation and apparent reversal of $\mathrm{Nb}$-Ta fractionaction in columbite-group minerals from the Scheibengraben beryl-columbite granitic pegmatite, Maršíkov, Czech Republic. Eur J Mineral 15: 565-574

PETRík I, Kонút M (1997) The evolution of granitoid magmatism during the Hercynian orogen in the Western Carpathians. In Grecula P, Hovorka D, Putiš M (eds.) Geological evolution of the Western Carpathians 235252. Miner Slov Monograph Bratislava

RaO C, WANG RC, Hu H, Zhang WL (2009) Complex internal textures in oxide minerals from the Nanping No. 31 dyke of granitic pegmatite, Fujian province, southeastern China. Can Mineral 47: 1195-1212

ŠKoda R, Novák M (2007) Y,REE,Nb,Ta,Ti-oxide (AB2O6) minerals from REL-REE euxenite-subtype pegmatites of the Třebič Pluton, Czech Republic; substitutions and fractionation trends. Lithos 95: 43-57
UHER P (2000) Stibiotantalit v pegmatite Sb ložiska Dúbrava - produkt hydrotermálnej alterácie kolumbitu-tantalitu. Miner Slov 32: 109-114

UHER P (2008) Columbit-tantalit z pegmatitu pri Ráztočne v pohorí Žiar (stredné Slovensko). Bull Mineral-Petrolog Odd Nár Muz 16(1): 109-112

UHeR P (2019) Granitové pegmatity Západných Karpát: súčasný stav poznatkov. Acta Mus Moraviae, Sci Geol 104(2): 139-167

Uher P, Broska I (1995) Pegmatites in two suites of Variscan orogenetic rocks (Western Carpathians, Slovakia). Mineral Petrol 55: 27-36

Uher P, Černý P, Novák M, Siman P (1994) Niobium-tantalum minerals from granitic pegmatites in the Malé Karpaty, Považský Inovec and Žiar Mountains, Western Carpathians, Slovakia. Miner Slov 26: 157-164

Uher P, Černyy P, Chapman R, Határ J, Miko O (1998a) Evolution of $\mathrm{Nb}$-Ta minerals in the Prašivá granitic pegmatites, Slovakia. I. Primary Fe,Ti-rich assemblage. Can Mineral 36: 525-534

Uher P, Černý P, Chapman R, Határ J, Miko O (1998b) Evolution of $\mathrm{Nb}$-Ta minerals in the Prašivá granitic pegmatites, Slovakia. II. External hydrothermal Pb, Sb overprint. Can Mineral 36: 535-545

UheR P, ŽitÑAn P, Ozdín D (2007) Pegmatitic Nb-Ta oxide minerals in alluvial placers from Limbach, Bratislava Massif, Western Carpathians, Slovakia: compositional variations and evolutionary trend. J Geosci 52: 133141

van Lichtervelde M, Salvi S, Beziat D, Linnen R (2007) Textural features and chemical evolution in tantalum oxides: magmatic versus hydrothermal origins for $\mathrm{Ta}$ mineralization in Tanco Lower pegmatite, Manitoba, Canada. Econ Geol 102: 257-276

VILINOVIČOVÁ L' (1990) Petrogenesis of gneisses and granitoids from the Strážovské vrchy Mts. Geol Zbor Geol Carpath 41: 335-376 